\title{
Effect of Different Level of N P K and Biochar on Soil Physico-chemical Properties, Yield and Attributes of Finger Millet (Eleusine Coracana) Var. - KM 65
}

\author{
Manjot Singh*, Tarence Thomas, Arun Alferd David and Narendra Swaroop
}

Department of Soil Science and Agricultural Chemistry, Naini Agricultural Institute [NAI], Sam Higginbottom University of Agriculture Technology and Sciences, Prayagraj, 211-007 U.P. India

*Corresponding author

\section{A B S T R A C T}

An experiment was conducted on "Effect of different level of N P K and Biochar on soil Physico-chemical properties, yield and attribute of Finger Millet (Eleusine coracana) Var.

\section{Keywords}

Finger millet, Soil, Urea, SSP, Biochar etc

\section{Article Info}

Accepted:

15 August 2020 Available Online: 10 September 2020
- KM 65" during Kharif season 2019-20 at the Research farm Department of Soil Science and Agricultural Chemistry, Naini Agriculture Institute, SHUATS, Prayagraj. The design applied was $3 \times 3$ randomized block design having three factors with three levels of N P K @ 0,50 , and $100 \% \mathrm{ha}^{-1}$, three levels of Biochar @ 0,50 and $100 \% \mathrm{ha}^{-1}$ respectively. The result obtained with treatment $\mathrm{T}_{9}-[\mathrm{N}$ P K $100 \%$ + Biochar $100 \%]$ that showed the highest yield regarding, gave the best results with respect to plant height $110.18 \mathrm{~cm}$, number of finger ear head ${ }^{-1} 7.42 \mathrm{~g}, 1000$ grain weight $3.48 \mathrm{~g}$, it gave highest yield $27.29 \mathrm{q} \mathrm{ha}^{-1}$ Biochar in combination resulted in a slight decrease in $\mathrm{pH} 6.78$ and EC increase $0.26 \mathrm{dS} \mathrm{m}^{-1}$. In post soil of $\mathrm{N} \mathrm{P} \mathrm{K}$ fertilizers observations were resulted in significant increase in OC $0.82 \%$, Particle density $2.63 \mathrm{Mg} \mathrm{m}^{-3}$, Bulk density $1.08 \mathrm{Mg} \mathrm{m}^{-3}$, Porespace $58.93 \%$ and

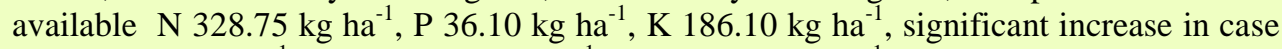
of Nitrogen $\left(\mathrm{kg} \mathrm{ha}^{-1}\right)$, Phosphorus $\left(\mathrm{kg} \mathrm{ha}^{-1}\right)$, Potassium $\left(\mathrm{kg} \mathrm{ha}^{-1}\right)$ was found to be significant among other treatments in finger millet cultivation and soil quality improvement. It was also revealed that the application of NPK with Biochar were excellent source for fertilization than fertilizers.

\section{Introduction}

Finger millet (Eleusine coraana) ranks 3rd in importance among all millets in the country in both area (1.38 million hectare) and production (2.03 matric tonnes) after the sorghum and pearl millet. Ragi is an important crop in dry land area due to its high resilience and ability to withstand aberrant weather conditions. In India and Africa, finger millet is one of the staple foods. In southern Karnataka, ragi is the main dietary component particularly grown in districts of Bangalore, Mysore, Mandya, Tumkur, Hassan and Chitradurga. The major finger millet growing states are Karnataka, Andhra Pradesh, Tamil Nadu, Orissa, Maharashtra, Jharkhand and Uttaranchal. Further ragi is 
also a good food for diabetic patients. The finger millet grains are rich in calcium, iron and carbohydrates. Finger millet is the staple food grain for majority of the population in India since it is economical and very nutritious. Dietary fiber protects against hyperglycemia, phytates against oxidation stress by chelating iron and some phenolics and tannins act as antioxidants. In south India, grains are used in many food preparations like cakes, porridge and sweetmeat. Germinating grains are malted and fed to infants also. It is also good for pregnant women. The finger millet flour is consumed by mixing with milk, boiled water or yoghurt. It is non acid forming food and easy to digest. It is considered to be one of the least allergic and most digestible foods (Pragya and Rita Singh, 2012). Finger millet is a small cereal grain with outstanding properties viz., strength of calcium (8.3 percent), iron (0.017 percent), dietary fibre and polyphenols (0.3 to 3 percent). Finger millet is rich in calcium content, about 10 times that of paddy or wheat (Stanly and Shanmugam, 2013). Besides this, it is a good source of essential amino acids of tryptophan, cystine and methionine and thus considered as a favourite wholesome food for hard toiling class and diabetic patients.

Soil is a medium for plant growth. Crop production is based largely on soils. Some of the soil properties affecting plant growth include: soil texture (coarse fine), aggregate size, porosity, aeration (permeability), and water holding capacity, $\mathrm{pH}$, bulk density, particle density. The rate of water movement into the soil (infiltration) is influenced by its texture, physical condition (soil structure and tilth), and the amount of vegetative cover on the soil surface. Organic matter tends to increase the ability of all soils to retain water, and also increases infiltration rates of fine textured soils. Bulk density reflects the soil's ability to function for structural support, water and solute movement, and soil aeration. Soil
$\mathrm{pH}$ directly affects the solubility of many of the nutrients in the soil needed for proper plant growth and development. As such, it is also a useful tool in making management decisions concerning the type of plants suitable for location, the possible need to modify soil $\mathrm{pH}$ (either up or down) and a rough indicator of the plant availability of nutrients in the soil.

In recent years, biochar has emerged as an important amendment with fertilizer and hold a key role to improve the yield of crops. The biochar has been found to have a great impact on soil fertility and increase in crop yield without causing any detorious hazards to the soil. Biochar is a fine-grained, highly porous charcoal substance that is differentiated from other charcoals in its use as a soil amendment.

The particular heat treatment of organic biomass used to produce biochar contributes to its large surface area and its characteristic ability to persist in soils with very little biological decay (Lehmann et al., 2006). While raw organic materials provide nutrients to plants and soil microorganisms, biochar acts as a catalyst that enhances plant uptake of nutrients and water. Compared to other soil amendments, the high surface area and porosity of biochar enable it to adsorb or retain nutrients and also provide food for beneficial microorganisms (Glaser et al., 2002, Lehmann et al., 2006, and Warnock et al., 2007).

Properties of Biochar and their composition: $\mathrm{pH}=9.90, \mathrm{EC}=3.53 \mathrm{dS} \mathrm{m}{ }^{-1}$, B.D. $=0.19 \mathrm{Mg}$ $\mathrm{m}^{-3}$, P.D. $=0.58 \mathrm{Mg} \mathrm{m}^{-3}$, W.H.C. $=58.5 \%, \mathrm{Zn}$ $=157 \mathrm{mg} \mathrm{kg}^{-1}, \mathrm{Mn}=214 \mathrm{mg} \mathrm{kg}^{-1}, \mathrm{Cu}=54$ $\mathrm{mg} \mathrm{kg}{ }^{-1}, \mathrm{Co}=3.43 \mathrm{mg} \mathrm{kg}^{-1}, \mathrm{Ni}=17.2 \mathrm{mg}$ $\mathrm{kg}^{-1}, \mathrm{~Pb}=45.5 \mathrm{mg} \mathrm{kg}^{-1}, \mathrm{Cd}=1.84 \mathrm{mg} \mathrm{kg}^{-1}, \mathrm{P}$ $=0.09 \%, \mathrm{~K}=3.22 \%, \mathrm{Na}=0.99 \%, \mathrm{Fe}=$ $0.28 \%, \mathrm{Ca}=0.38 \%, \mathrm{Mg}=0.25 \%, \mathrm{Al}=1.83 \%$ (Bird et al., 2011). 
Nitrogen is an important nutrient for all crops. It increases yield nutrition also increases the protein content. Deficient plants may have stunted growth and develop yellow-green colour. It accelerates photosynthetic behaviour of green plants as well as growth and development of living tissues specially tiller count in cereals. Phosphorus is the second most important nutrient that must be added to the soil to maintain plant growth and sustain crop yield (Patil et al., 2011). Phosphorus plays a vital role in photosynthesis, respiration, energy storage, cell elongation and improves the quality of crops. Deficient plants may have thin, erect and spindly stems and leaves turn into bluishgreen colour. Phosphorus is an essential constituent of majority of enzymes, which are of great importance in the transformation of energy, in carbohydrate metabolism, in fat metabolism and also in respiration of plants. Potassium is one of the seventeen elements which are essential for growth and development of plants. Potassium is required for improving the yield and quality of different crops because of its effect on photosynthesis, water use efficiency and plant tolerance to diseases, drought and cold as well for making the balance between protein and carbohydrates (Singh and Yadav, 2008). Potassium enhances the ability of plants to resist diseases, insect-pest attack, cold, drought and other adversities.

\section{Materials and Methods}

The experiment was conducted at Research Farm of Soil Science and Agricultural Chemistry at Sam Higginbottom University of Agriculture Technology and Sciences, Prayagraj. The area situated on the south of Prayagraj on the right side of the river Yamuna on the South of Rewa Road at a distance of about $6 \mathrm{Km}$ from Prayagraj city. It is situated at $25^{\circ} 58^{\prime}$ North latitude and $81^{\circ} 52^{\prime}$ East longitude and at the altitude of 98 meter above the sea level. The area of Prayagraj district comes under subtropical belt in the South east of Uttar Pradesh, which experience extremely hot summer and cold winter. The maximum temperature of the location reaches up to $46^{\circ} \mathrm{C}-48^{\circ} \mathrm{C}$ and seldom falls as low as $4 \mathrm{C}-5^{\circ} \mathrm{C}$. The relative humidity ranged between 20 to 94 percent. The average rainfall in this area is around $1100 \mathrm{~mm}$ annually. The Soils of experimental area falls in order of Inceptisol and soil was alluvial. The soil samples were randomly collected from five different sites in the experimental plot prior to tillage operation from a depth of $0-15 \mathrm{~cm}$. The size of the soil sample were reduced by conning and quartering the composites soil samples were air dried and passed through a $2 \mathrm{~mm}$ sieve by way of preparing the sample for physical and chemical analysis. Finger Millet var. KM 65 Selection from exotic germplasm CSAUA\&T, Kanpur 1994 Uttar Pradesh. This variety has early maturity and resistant from blast.

\section{Results and Discussion}

As depicted in tables maximum Bulk density $\left(\mathrm{Mg} \mathrm{m}^{-3}\right)$ of soil was recorded $1.28 \mathrm{Mg} \mathrm{m}^{-3}$ in treatment $\mathrm{T}_{1}$ (control) and minimum Bulk density $\left(\mathrm{Mg} \mathrm{m}^{-3}\right)$ of soil was recorded 1.08 $\mathrm{Mg} \mathrm{m}^{-3}$ in treatment $\mathrm{T}_{9}\left(\mathrm{~N}_{20} \mathrm{P}_{40} \mathrm{~K}_{40}+100 \%\right.$ Biochar). Similar results were also reported by (Chintala et al., 2014). Particle density $\left(\mathrm{Mg} \mathrm{m}^{-3}\right)$ of soil was recorded $2.63 \mathrm{Mg} \mathrm{m}^{-3}$ in treatment $\mathrm{T}_{9}\left(\mathrm{~N}_{20} \mathrm{P}_{40} \mathrm{~K}_{40}+100 \%\right.$ Biochar $)$ and minimum Particle density $\left(\mathrm{Mg} \mathrm{m}^{-3}\right)$ of soil was recorded $2.36 \mathrm{Mg} \mathrm{m}^{-3}$ in treatment $\mathrm{T}_{1}$ (control). Similar results were also reported by (chan et al.,) and (Chintala et al., 2014). Soil pore space was recorded $58.93 \%$ in treatment $\mathrm{T}_{9}\left(\mathrm{~N}_{20} \mathrm{P}_{40} \mathrm{~K}_{40}+100 \%\right.$ Biochar $)$ and minimum soil pore space was recorded $45.76 \%$ in treatment $\mathrm{T}_{1}$ (Control). Similar results were also reported by (chan et al.,) and (Chintala et al., 2014). Soil pH was recorded 7.18 in treatment $\mathrm{T}_{1}$ (control) and minimum 
soil $\mathrm{pH}$ was recorded 6.78 in treatment $\mathrm{T}_{9}$ $\left(\mathrm{N}_{20} \mathrm{P}_{40} \mathrm{~K}_{40}+100 \%\right.$ Biochar). Similar results were also reported by (chan et al.,) and (Chintala et al., 2014). EC ( $\left.\mathrm{dS} \mathrm{m}^{-1}\right)$ of soil was recorded $0.26 \mathrm{dS} \mathrm{m}^{-1}$ in treatment $\mathrm{T}_{9}\left(\mathrm{~N}_{20}\right.$ $\mathrm{P}_{40} \mathrm{~K}_{40}+100 \%$ Biochar) and minimum EC $\left(\mathrm{dS} \mathrm{m} \mathrm{m}^{-1}\right.$ ) of soil was recorded $0.12 \mathrm{dS} \mathrm{m}^{-1}$ in treatment $\mathrm{T}_{1}$ (control). Similar results were also reported by (chan et al.,) and (Chintala et al., 2014). The maximum \% Organic carbon in soil was recorded $0.82 \%$ in treatment $\mathrm{T}_{9}$ $\left(\mathrm{N}_{20} \mathrm{P}_{40} \mathrm{~K}_{40}+100 \%\right.$ Biochar $)$ which was significantly higher than any other treatment combination and the minimum \% Organic carbon in soil was recorded $0.65 \%$ in treatment $\mathrm{T}_{1}$ (control). Similar findings were recorded by (chan et al.,) and (Chintala et al., 2014). The highest available Nitrogen in soil was recorded $328.75\left(\mathrm{Kg} \mathrm{ha}^{-1}\right)$ in treatment $\mathrm{T}_{9}$ $\left(\mathrm{N}_{20} \mathrm{P}_{40} \mathrm{~K}_{40}+100 \%\right.$ Biochar $)$ which was significantly higher than any other treatment combination and the minimum available Nitrogen in soil was recorded 287.50 $\left(\mathrm{Kg} \mathrm{ha}^{-1}\right)$ in treatment $\mathrm{T}_{1}$ (control). Similar findings were also recorded by (Pallavi et al., 2016) and (Gajbhaiya et al., 2017). The highest available Phosphorus in soil was recorded $36.10\left(\mathrm{Kg} \mathrm{ha}^{-1}\right)$ in treatment $\mathrm{T}_{9}\left(\mathrm{~N}_{20}\right.$ $\mathrm{P}_{40} \mathrm{~K}_{40}+100 \%$ Biochar) which was significantly higher than any other treatment combination and the minimum available Phosphorus in soil was recorded $24.12(\mathrm{Kg}$ $\mathrm{ha}^{-1}$ ) in treatment $\mathrm{T}_{1}$ (control). Similar findings were also recorded by (Pallavi et al., 2016) and (Gajbhaiya et al., 2017) (Fig. 1 and 2; Table 1-5).

Table.1 Treatment Combination for Finger millet

\begin{tabular}{|c|l|l|}
\hline S. No. & \multicolumn{1}{|c|}{ Symbol } & \multicolumn{1}{c|}{ Description } \\
\hline 1. & $\mathrm{~T}_{1}-\mathrm{L}_{0} \mathrm{~B}_{0}$ & {$[0 \% \mathrm{NPK}+0 \%$ Biochar $]$} \\
\hline 2. & $\mathrm{~T}_{2}-\mathrm{L}_{0} \mathrm{~B}_{1}$ & {$[0 \% \mathrm{NPK}+50 \%$ Biochar $]$} \\
\hline 3. & $\mathrm{~T}_{3}-\mathrm{L}_{0} \mathrm{~B}_{2}$ & {$[0 \% \mathrm{NPK}+100 \%$ Biochar $]$} \\
\hline 4. & $\mathrm{~T}_{4}-\mathrm{L}_{1} \mathrm{~B}_{0}$ & {$[50 \% \mathrm{NPK}+0 \%$ Biochar $]$} \\
\hline 5. & $\mathrm{~T}_{5}-\mathrm{L}_{1} \mathrm{~B}_{1}$ & {$[50 \% \mathrm{NPK}+50 \%$ Biochar $]$} \\
\hline 6. & $\mathrm{~T}_{6}-\mathrm{L}_{1} \mathrm{~B}_{2}$ & {$[50 \% \mathrm{NPK}+100 \%$ Biochar $]$} \\
\hline 7. & $\mathrm{~T}_{7}-\mathrm{L}_{2} \mathrm{~B}_{0}$ & {$[100 \% \mathrm{NPK}+0 \%$ Biochar $]$} \\
\hline 8. & $\mathrm{~T}_{8}-\mathrm{L}_{2} \mathrm{~B}_{1}$ & {$[100 \% \mathrm{NPK}+50 \%$ Biochar $]$} \\
\hline 9. & $\mathrm{~T}_{9}-\mathrm{L}_{2} \mathrm{~B}_{2}$ & {$[100 \% \mathrm{NPK}+100 \%$ Biochar $]$} \\
\hline
\end{tabular}

Table.2 Physical analysis of soil (pre-sowing sample)

\begin{tabular}{|c|c|c|}
\hline Particulars & Results & Method employed \\
\hline Sand (\%) & 62.71 & \\
\hline Clay (\%) & 23.10 & Bouyoucos Hydrometer (1952) \\
\hline Silt (\%) & 14.19 & \\
\hline Texural class & Sandy loam & \\
\hline Soil colour & & Munsell Colour Chart (1971) \\
\hline Dry Soil & Pale brown Colour & \\
\hline Wet Soil & Olive brown Colour & \\
\hline Bulk density $\left(\mathrm{Mg} \mathrm{m}^{-3}\right)$ & 1.23 & Graduated Measuring Cylinder \\
\hline Particle density $\left(\mathrm{Mg} \mathrm{m}^{-3}\right)$ & 2.37 & (Muthuvel et al., 1992) \\
\hline Pore Space $(\%)$ & 47.53 & \\
\hline
\end{tabular}


Table.3 Chemical analysis of soil (pre-soil samples)

\begin{tabular}{|c|c|c|}
\hline Parameters & Method employed & Results \\
\hline Soil pH (1:2) & Glass electrode, $\mathrm{pH}$ meter & 7.58 \\
\hline Soil EC $\left(\mathrm{dS} \mathrm{m}^{-1}\right)$ & EC meter (Conductivity Bridge) & 0.177 \\
\hline Organic Carbon (\%) & $\begin{array}{l}\text { Wet Oxidation Method } \\
\text { (Walkley and Black's 1947) }\end{array}$ & 0.45 \\
\hline Available Nitrogen $\left(\mathrm{Kg} \mathrm{ha}^{-1}\right)$ & $\begin{array}{l}\text { Kjeldhal Method } \\
\text { (Subbaih and Asija, 1956) }\end{array}$ & 238.21 \\
\hline Available Phosphorus $\left(\mathrm{Kg} \mathrm{ha}^{-1}\right)$ & $\begin{array}{l}\text { Colorimetric method } \\
\text { (Olsen et al. 1954) }\end{array}$ & 20.73 \\
\hline Available Potassium $\left(\mathrm{Kg} \mathrm{ha}^{-1}\right)$ & $\begin{array}{l}\text { Flame photometric method } \\
\text { (Toth and Price, 1949) }\end{array}$ & 127.65 \\
\hline
\end{tabular}

Table.4 Physical properties of soil sample after harvesting of finger millet

\begin{tabular}{|c|c|c|c|}
\hline Treatment & Bulk Density $\left(\mathrm{Mg} \mathrm{m}^{-3}\right)$ & Particle Density $\left(\mathrm{Mg} \mathrm{m}^{-3}\right)$ & Pore space $(\%)$ \\
\hline $\mathbf{T}_{1}$ & 1.28 & 2.36 & 45.76 \\
\hline $\mathbf{T}_{2}$ & 1.26 & 2.38 & 47.06 \\
\hline $\mathbf{T}_{3}$ & 1.22 & 2.41 & 49.38 \\
\hline $\mathbf{T}_{4}$ & 1.18 & 2.45 & 51.83 \\
\hline $\mathbf{T}_{5}$ & 1.17 & 2.50 & 53.20 \\
\hline $\mathbf{T}_{6}$ & 1.15 & 2.53 & 54.54 \\
\hline $\mathbf{T}_{7}$ & 1.12 & 2.56 & 56.25 \\
\hline $\mathbf{T}_{8}$ & 1.10 & 2.59 & 57.52 \\
\hline $\mathbf{T}_{9}$ & 1.08 & 2.63 & 58.93 \\
\hline F-test & NS & NS & $\mathrm{S}$ \\
\hline S. Em \pm & 0.05 & 0.33 & 1.38 \\
\hline C.D & 0.11 & 0.69 & 2.94 \\
\hline
\end{tabular}

Table.5 Chemical properties of soil sample after harvesting of finger millet

\begin{tabular}{|c|c|c|c|c|c|c|}
\hline Treatments & pH & 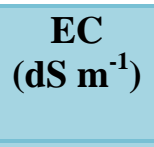 & $\begin{array}{c}\text { Organic } \\
\text { carbon } \\
(\%)\end{array}$ & $\begin{array}{l}\text { Available } \\
\text { Nitrogen } \\
\left(\mathrm{Kg} \mathrm{ha}^{-1}\right)\end{array}$ & $\begin{array}{c}\text { Available } \\
\text { Phosphorus } \\
\left(\mathrm{Kg} \mathrm{ha}^{-1}\right)\end{array}$ & $\begin{array}{c}\text { Available } \\
\text { potassium } \\
\left(\mathrm{Kg} \mathrm{ha}^{-1}\right)\end{array}$ \\
\hline $\mathbf{T}_{1}$ & 7.18 & 0.12 & 0.65 & 287.50 & 24.12 & 130.25 \\
\hline $\mathbf{T}_{2}$ & 7.15 & 0.15 & 0.68 & 292.75 & 25.15 & 135.10 \\
\hline $\mathbf{T}_{3}$ & 7.05 & 0.18 & 0.68 & 301.80 & 27.85 & 140.38 \\
\hline $\mathbf{T}_{4}$ & 7.04 & 0.20 & 0.70 & 302.55 & 28.10 & 152.05 \\
\hline $\mathbf{T}_{5}$ & 7.01 & 0.22 & 0.65 & 310.12 & 29.05 & 154.10 \\
\hline $\mathbf{T}_{6}$ & 6.96 & 0.22 & 0.75 & 318.85 & 30.15 & 162.28 \\
\hline $\mathbf{T}_{7}$ & 6.95 & 0.24 & 0.69 & 320.65 & 31.30 & 168.36 \\
\hline $\mathbf{T}_{8}$ & 6.88 & 0.25 & 0.72 & 324.92 & 34.28 & 178.52 \\
\hline $\mathbf{T}_{9}$ & 6.78 & 0.26 & 0.82 & 328.75 & 36.10 & 186.10 \\
\hline F-test & $\mathrm{S}$ & NS & $\mathrm{S}$ & $\mathrm{S}$ & S & $\mathrm{S}$ \\
\hline S. Em. \pm & 0.06 & 0.28 & 0.01 & 3.24 & 0.56 & 7.78 \\
\hline C.D. $(P=0.05)$ & 0.12 & 0.06 & 0.03 & 6.87 & 1.18 & 16.49 \\
\hline
\end{tabular}


Fig.1 Physical properties of soil sample after harvesting of finger millet

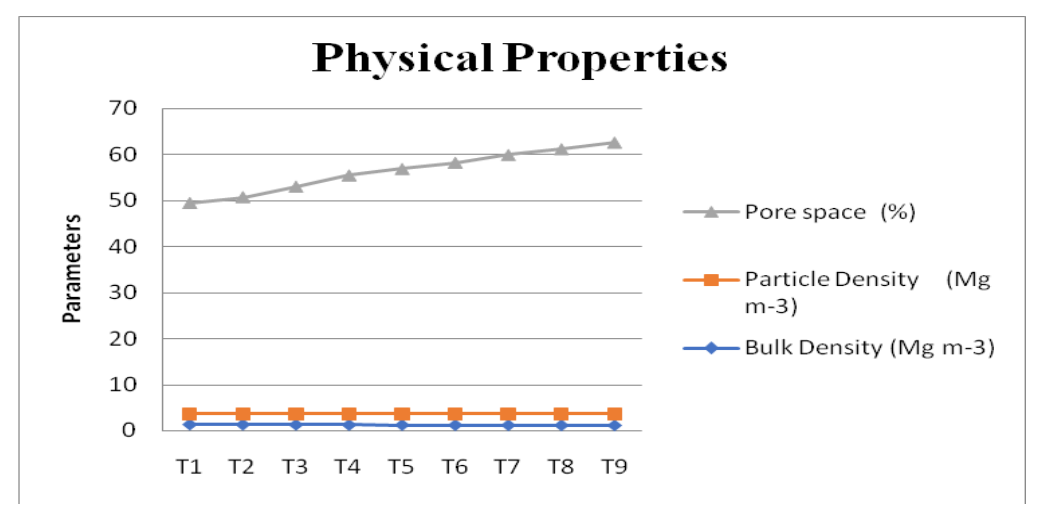

Fig.2 Chemical properties of soil sample after harvesting of finger millet

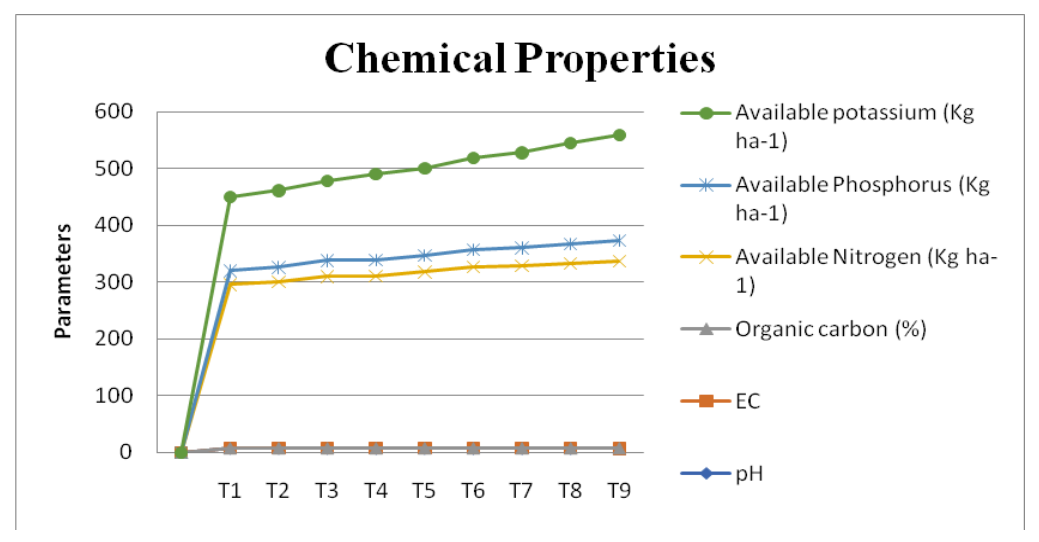

The highest available Potassium in soil was recorded $186.10\left(\mathrm{Kg} \mathrm{ha}^{-1}\right)$ in treatment $\mathrm{T}_{9}$ $\left(\mathrm{N}_{20} \mathrm{P}_{40} \mathrm{~K}_{40}+100 \%\right.$ Biochar) which was significantly higher than any other treatment combination and the minimum available Potassium in soil was recorded $130.25(\mathrm{Kg}$ $\mathrm{ha}^{-1}$ ) in treatment $\mathrm{T}_{1}$ (control). Similar findings were also recorded by (Pallavi et al., 2016) and (Gajbhaiya et al., 2017).

Summary and conclusion are as follows:

The salient findings of the present investigation are summarized as follows.

The soil texture observed was sandy loamy. The soil colour in dry condition was light yellowish brown and wet condition was olive brown. The soil $\mathrm{pH}$ was 7.18 and Bulk density $1.08 \mathrm{Mg} \mathrm{m}^{-3}$, has resulted due to the application of $\mathrm{N} \mathrm{P} \mathrm{K}$ and Biochar while Particle density $2.63 \mathrm{Mg} \mathrm{m}^{-3}$, Pore space $58.93 \%$, Electrical conductivity $0.26 \mathrm{dS} \mathrm{m}^{-1}$, Organic carbon $0.82 \%$, respectively Nitrogen $328.75 \mathrm{~kg} \mathrm{ha}^{-1}$, Phosphorus $36.10 \mathrm{~kg} \mathrm{ha}^{-1}$ and Potassium $186.10 \mathrm{~kg} \mathrm{ha}^{-1}$, has increase by the application of $\mathrm{N} \mathrm{P} \mathrm{K}$ and Biochar. The best treatment was $\mathrm{T}_{9}-\mathrm{L}_{2} \mathrm{~B}_{2}$ [@100\% N P K + @ $100 \%$ Biochar]. In post soil the important parameter on chemical properties on black gram crop different treatment of N P K and Biochar, percentage pore space, $\mathrm{pH}$, organic carbon $(\%)$, Nitrogen $\left(\mathrm{kg} \mathrm{ha}^{-1}\right)$, phosphorus $\left(\mathrm{kg} \mathrm{ha} \mathrm{h}^{-1}\right)$, potassium $\left(\mathrm{kg} \mathrm{ha}{ }^{-1}\right)$ respectively were found significant and EC was found non-significant. $\mathrm{pH}$, organic carbon (\%), available nitrogen $\left(\mathrm{kg} \mathrm{ha}^{-1}\right)$, phosphorus $(\mathrm{kg}$ $\left.\mathrm{ha}^{-1}\right)$, and potassium $\left(\mathrm{kg} \mathrm{ha}^{-1}\right)$ was recorded as $7.18, \quad 0.82, \quad 328.75, \quad 36.10$, and 186.10 respectively. 
It was concluded from trail that treatment $\mathrm{T}_{9}$ $\mathrm{L}_{2} \mathrm{~B}_{2}$ [@100\% N P K + @ 100\% Biochar] gave the most significant findings in terms of soil properties and yield attributes of Finger Millet var. KM-65, N P K and Biochar. Biochar increases soil organic matter content in soil, it's can improve soil health and enhance the yield of Finger Millet.

\section{Acknowledgement}

I am grateful for ever-inspiring guidance, constant encouragement, keen interest, comments and constructive suggestions throughout the course of my studies and investigation, from, head of the department and staff, department of Soil Science and Agricultural Chemistry, Sam Higginbottom University of Agriculture, Technology and Sciences, Prayagraj, Uttar Pradesh.

\section{References}

Bird, M. I., Wurster, C. M., Silva, P., Bass, A. M. and De Nye, R. (2011) Algalbiochar - production and properties. Bioresource Technology, 102: 1886 1891.

Bouyoucos, G. J. (1927) The hydrometer as a new method for the mechanical analysis of soils. Soil Sci., 23: 393-39.

Chan, K. Y., Van Zwieten, L., Meszaros, I., Downie, A. and Joseph, S., (2007) Agronomic values of green waste biochar as a soil amendment. Australian. J. Soil Res., 45: 629-634.

Chintala, R., Javier, M., Thomas, E. S. and Douglas, D. M., (2014) Effect of biochar on chemical properties of soil. Archeive Agron. Soil Sci., 60(3): 393404.

Gajbhaiya, P. N., Nigade, R. D., and Bulbule, A. V. (2017) Sustaining Soil Fertility and Yields of Finger Millet (Eleusine coracana L.) through Balanced Fertilization.
Jackson, M.L (1958) The pH was determined in 1:2 soil water suspensions using digital $\mathrm{pH}$ meter.

Lehmann, J., Gaunt, J. and Rondon, M., (2006) Biochar sequestration in terrestrial ecosystems: A review. Mitig. Adapt. Strat. Gl. Chn, 11: 403-427.

Munsell, A.H., ed. 12, (1971) Baltimore, MD: Munsell Color Company. pp.- 65.

Muthuvel P., C. Udaysoorian, R. Natesan, P.P. Ramaswami, (1992) Introduction to Soil analysis, Tamil Nadu Agricultural University, Coimbatore-641002.

Olsen, S.R., Watanale, F.S., (1954) A method to determine a phosphorus adsorption measured by colorimetric method soil sci. soc. Am. J. 21, 144-149.

Pallavi, C., Joseph, B., Khan, M. A., and Hemalatha, S. (2016) Effect of integrated nutrient management on nutrient uptake, soil available nutrients and productivity of finger millet. International Journal of Science, Environment and Technology, 5(5), 2798-2813.

Patil, P. P., Shinde, A. K., Gadhave, P. M., Chavan, A. P., and Mahadkar, U. V. (2018) Effect of sowing methods, nutrient management and seed priming on seed yield and yield attributes of finger millet (Eleusine coracana G.). Advanced Agricultural Research and Technology Journal, 12-17.

Pragya, S and Rita Singh, R. (2012) Finger millet for food and nutritional security. African Journal of Food Science. 6(4): 77-84.

Singh R.S. and Yadav M.K. (2008) Effect of phosphorus and biofertilizers on growth, yield and nutrient uptake of long duration pigeonpea under rainfed condition. Journal of Food Legumes, 21(1):46-48.

Stanly, M. J. and Shanmugam, A. (2013) A study on millets based cultivation and consumption in India. International 
Journal of Marketing, Financial Services and Management Research. 2(4): 49-58.

Subbiah, B.V. and Asija (1956) A rapid procedure for estimation of available nitrogen in soils. Curr. Sci. 25:259.

Toth, S.J., A.L. Prince (1949) Estimation of cation exchange capacity and exchangeable calcium, potassium and sodium contents of soils by flame photometer techniques. Soil sci. 67,
439-445.

Walkley, A. and Black, I. A. (1947) Critical examination of rapid method for determining organic carbon in soils, effect of variance in digestion conditions and of inorganic soil constituents. Soil sci. pp. 632: 251.

Wilcox (1950) Electrical conductivity. Am water work Assoc. J 42; pp. 775-776.

\section{How to cite this article:}

Manjot Singh, Tarence Thomas, Arun Alferd David and Narendra Swaroop. 2020. Effect of Different Level of N P K and Biochar on Soil Physico-chemical Properties, Yield and Attributes of Finger Millet (Eleusine Coracana) Var. - KM 65. Int.J.Curr.Microbiol.App.Sci. 9(09): 1904-1911. doi: https://doi.org/10.20546/ijcmas.2020.909.240 